\title{
Sistem Informasi Koperasi Simpan Pinjam Pada PT Meiwa Indonesia Berbasis Java
}

\author{
Nurrihman ${ }^{1}$, Rudi Apriyadi Raharjo ${ }^{2}$, Anggun Citra Dini Dwi Puspitasari ${ }^{3}$ \\ ${ }^{1,2,3}$ Program Studi Teknik Informatika Universitas Indraprasta PGRI, Jl Raya Tengah No.80, Rt 06/Rw 01, Gedong, Kec. Ps.Rebo,Jaktim 13760 \\ 11Nurrohman1996@gmail.com
}

INFORMASI ARTIKEL

Sejarah Artikel:

Diterima Redaksi: 28-01-2020

Revisi Akhir: 27-06-2020

Diterbitkan Online: 25-10-2020

\begin{tabular}{l} 
KATA KUNCI \\
\hline Sistem, \\
Informasi, \\
Koperasi, \\
Simpan Pinjam, \\
Pengolahan Data \\
KORESPONDENSI \\
\hline
\end{tabular}

Telepon: +62 81299023796

E-mail: rinadeviana22@gmail.com

\section{A $\quad$ B $\quad S \quad T \quad R A$ C $\mathbf{T}$}

The purpose of this research is to make a Java-based savings and loan cooperative information system design to accelerate and facilitate performance in managing the search and storage of loan data at cooperatives as well as to produce a Java-based savings and credit cooperative information system. The research method used by researchers is the grounded research method, which is a research method based on facts and uses comparative analysis with the aim of conducting empirical generation, establishing concepts, proving theories, developing theories, collecting data and analyzing data in the same time. The results obtained are designing a savings and loan cooperative information system to assist in processing employee data. The construction of this information system is expected to simplify and provide maximum service for employees as well as to facilitate cooperative staff in collecting loan transaction data for reporting, data and information management processes become more effective, produce faster outputs and there is no misappropriation of loan data input or the occurrence of data duplication.

\section{PENDAHULUAN}

Perkembangan teknologi informasi dalam berbagai bidang kehidupan semakin pesat, mendorong manusia untuk berlomba memanfaatkan informasi sesuai dengan kebutuhan tujuannya. Pemanfaatan teknologi informasi dalam suatu perusahaan tentunya disesuaikan dengan kebutuhan dari desain sistem di perusahaan tersebut. Teknologi tidak lagi dipandang hanya sebagai pelengkap, tetapi sudah menjadi salah satu penentu atas terlaksananya sasaran dan strategi dari perusahaan. Pengolahan data yang dikerjakan secara manual sudah tidak lagi diperlukan.

Kebutuhan setiap orang memang berbeda-beda, khususnya dalam hal keuangan. Makin tinggi pendapatan seseorang maka makin tinggi pula pengeluaran keuangan seseorang dan sebaliknya pula. Banyak perusahaan di zaman seperti ini menawarkan paket kredit dengan jangka waktu tertentu. Dalam hal ini, Koperasi Simpan Pinjam PT Meiwa Indonesia juga melakukan hal yang serupa.

Penyajian sistem informasi yang lebih baik dan cepat merupakan serangkaian proses yang diharapkan bisa memajukan perkembangan suatu perusahaan ke arah yang lebih baik. Untuk menyejahterakan anggota dan untuk membuat perekonomian anggota koperasi menjadi lebih baik, maka perusahaan perlu melakukan komputerisasi sistem dan pengolahan data yang baik di dalam perusahaan maupun untuk proses transaksi simpan pinjam koperasi pada perusahaan tersebut. Selain itu data yang dihasilkan tersebut dapat dijadikan bahan pertimbangan untuk memutuskan kebijakan operasional dan kebijakan lainnya.

Sistem Informasi Koperasi Simpan Pinjam pada PT Meiwa Indonesia belum dilakukan secara efektif dan efisien, akibatnya sering menimbulkan permasalahanpermasalahan seperti sering terjadi kesalahan penginputan data pada koperasi dikarenakan kurang ketelitian, terjadi kesalahan dalam proses transaksi peminjaman pada koperasi. Untuk itu, perlu adanya suatu sistem yang terkomputerisasi dengan baik yang mempercepat pelayanan informasi simpan pinjam pada PT Meiwa Indonesia dan mempercepat pencarian informasi tentang koperasi itu sendiri.

\section{TINJAUAN PUSTAKA}

\subsection{Sistem}

Istilah sistem dari bahasa Yunani yaitu sistem yang mengandung inti kesatuan atau keseluruhan bagian-bagian yang berhubungan dengan yang lainnya. Sistem adalah sekumpulan objek yang merupakan suatu wadah terdiri dari beberapa subsistem yang saling berhubungan, didalam hubungan tersebut terdapat beberapa ketergantungan antara satu dan yang lainnya, dalam arti bahwa jika ada 
sistem yang satu dari pada subsistem tidak berfungsi maka sistem tersebut akan terganggu. Sistem adalah kumpulan dari komponen apapun yang saling berhubungan satu sama lain dan bekerja sama secara harmonis untuk mencapai satu tujuan tertentu [1].

Sistem dapat diklasifikasikan menurut beberapa sudut pandang [2], antara lain :

a. Sistem Abstrak dan Sistem Fisik

Sistem abstrak (abstract system) adalah sistem yang berupa pemikiran atau ide-ide yang tidak tampak secara fisik. Sedangkan sistem fisik (physical system) adalah sistem yang ada secara fisik dan dapat dilihat.

b. Sistem Alamiah dan Sistem Buatan Manusia

Sistem alamiah (natural system) adalah sistem yang terjadi melalui proses alam (tidak dibuat oleh manusia). Sedangkan sistem buatan manusia (human made system) adalah sistem yang melibatkan hubungan manusia dengan mesin, yang disebut dengan human machine system.

c. Sistem Deterministik dan Sistem Probabilistik

Sistem deterministik (deterministic system) adalah suatu sistem yang beroperasi dengan tingkah laku yang dapat diprediksi. Sedangkan sistem probabilistik (probabilistic system) adalah sistem yang kondisi masa depannya tidak dapat diprediksi karena mengandung unsur probabilitas.

\section{d. Sistem Terbuka dan Tertutup}

Sistem terbuka (open system) adalah sistem yang berhubungan dan dipengaruhi oleh lingkungan luarnya, yang menerima masukan dan menghasilkan keluaran untuk subsistem lainnya. Sedangkan sistem tertutup (closed system) adalah sistem yang tidak berhubungan dan tidak dipengaruhi oleh lingkungan luarnya. Sistem ini bekerja secara otomatis tanpa ada campur tangan dari pihak luar.

Sistem adalah suatu jaringan kerja dari prosedurprosedur yang saling berhubungan, berkumpul bersamasama untuk melakukan suatu kegiatan atauuntuk menyelesaikan suatu sasaran tertentu [3].

Sebuah sistem memiliki karakteristik atau sifat-sifat yang mencirikan bahwa hal tersebut bisa dikatakan sebagai suatu sistem, diantaranya:

a. Komponen Sistem (Component)

Suatu sistem terdiri dari sejumlah komponen yang saling berinteraksi, yang artinya saling bekerja sama membentuk satu kesatuan. Komponen-komponen sistem atau elemen-elemen sistem dapat berupa suatu subsistem atau bagian-bagian dari sistem. Setiap elemen subsistem mempunyai sifat dari sistem untuk menjalankan fungsi tertentu mempengaruhi proses sistem secara keseluruhan.

b. Batasan Sistem (Boundary)

Merupakan daerah yang membatasi antara suatu sistem dengan sistem yang lainnya atau dengan lingkungan luarnya. Batasan suatu sistem menunjukkan ruang lingkup dari sistem tersebut.

c. Lingkungan luar sistem (Environment)

Lingkungan luar dari suatu sistem adalah apapun diluar batas sistem yang mempengaruhi operasi. Lingkungan luar sistem dapat bersifat menguntungkan dan dapat juga bersifat merugikan sistem tersebut. Lingkungan luar yang menguntungkan berupa energy dari sistem dan dengan demikian harus tetap dijaga dan dipelihara. Sedangkan lingkungan luar yang merugikan harus di tahan dan dikembalikan, kalau tidak maka akan mengganggu kelangsungan hidup dari sistem.

d. Penghubung sistem (Interface)

Merupakan media penghubung antara satu subsistem dengan subsistem lainnya.Dengan penghubung subsistem, dapat berintegras dengan subsistem yang lainnya membentuk satu kesatuan

e. Masukan sistem (input)

Masukan sistem adalah energi yang diterima kedalam sistem. Masukan dapat berupa masukan perawatan (maintenance input), dan masukan sinyal (signal input). Perawatan input adalah energi yang dimasukan supaya sistem tersebut dapat beroperasi, sedangkan sinyal input adalah energi yang diproses untuk didapatka keluaran. Sebagai contoh didalam komputer ada data adalah sebagai sinyal input untuk diolah menjadi informasi.

f. Keluaran sistem (output)

Keluaran sistem adalah hasil dari energi yang diolah dan diklasifikasikan menjadi keluaran yang berguna dan sisa pembuangan. Misalnya untuk sistem komputer, panas yang dihasilkan adalah keluaran yang tidak berguna dan merupakan hasil sisa pembuangan, sedangkan informasi adalah keluaran yang dibutuhkan.

g. Pengolahan sistem (process)

Suatu sistem dapat mempunyai suatu bagian pengolah yang akan merubah masukan menjadi keluaran. Suatu sistem produksi akan mengolah masukan berupa bahan baku dan bahan-bahan yang lain menjadi keluaran berupa bahan jadi.

h. Sasaran sistem (objective)

Sebuah sistem sudah tentu mempunyai sasaran atau tujuan. Dengan adanya sasaran sistem, maka kita dapat menentukan masukan yang dibutuhkan sistem dan keluaran apa yang dihasilkan sistem tersebut dapat dikatakan berhasil apabila mencapai sasaran atau tujuan.

\subsection{Konsep Dasar Sistem Informasi}

\section{a. Pengertian Sistem Informasi}

Sistem informasi adalah sistem yang dapat didefinisikan dengan mengumpulkan, memproses, menyimpan, menganalisis, menyebarkan infomasi untuk tujuan tertentu. Seperti sistem lainnya, sebuah sistem informasi terdiri atas input (data, instruksi) dan output (laporan, kalkulasi) [4].

Sistem informasi adalah suatu kesatuan yang utuh dari beberapa bagian yang saling berhubungan dan saling berinteraksi untuk mencapai tujuan [5].

Dari beberapa definisi di atas, dapat disimpulkan bahwa sistem informasi adalah suatu sistem yang terdiri dari kumpulan komponen-komponen sistem, yang memproses informasi menjadi sebuah output yang berguna untuk mencapai tujuan tertentu dalam suatu organisasi. Suatu sistem informasi pada dasarnya terbentuk melalui suatu kelompok kegiatan operasi yang tetap, yaitu mengumpulkan data, mengelompokkan data, menghitung, menganalisa, dan menyajikan laporan. 


\section{b. Komponen Sistem Informasi}

Komponen sistem informasi merupakan komponenkomponen dari subsistem yang saling berhubungan dan bekerja sama secara harmonis unuk mencapai suatu tujuan yaitu mengolah data menjadi informasi [6].

\subsection{Koperasi}

Koperasi adalah suatu badan usaha yang bertujuan untuk memberikan atau memudahkan anggota mendapatkan modal serta mendapatkan kebutuhan pokok dan penyaluran beras secara rutin dengan berazaskan kekeluargaan serta dapat memberikan pelayanan usaha simpan pinjam untuk anggota sendiri. Adapun syaratsyarat yang dapat diterima menjadi anggota koperasi dalam Anggaran Dasar adalah:

a. Mempunyai kemampuan penuh untuk melakukan tindaan hukum

b. Mata pencarian guru, karyawan/karyawati

c. Telah menyatakan kemampuan dan kesanggupan secara teratur untuk melunasi simpanan pokok dan membayar simpanan wajib secara teratur sebagaimana yang dimaksud pasal 29 ayat 1

d. Bersedia menjadi pengguna jasa koperasi

e. Mempunyai kemampuan dan bersedia untuk berpartisipasi dalam kegiatan usaha koperasi

f. Mempunyai kemampuan mengembangkan kebersamaan

g. Telah menyetujui isi anggaran dasar dan ketentuanketentuan koperasi yang berlaku

\subsection{Simpan Pinjam}

Koperasi simpan pinjam atau koperasi kredit adalah Koperasi yang bergerak dalam pemupukan simpanan dari anggotanya untuk dipinjamkan kembali kepada anggotanya yang membutuhkan bantuan modal unuk usahanya [7].

Koperasi pada dasarnya adalah usaha yang harus dapat memenuhi kebutuhannya dari kemampuannya sendiri. Dengan demikian tujuan didirikannya Koperasi Simpan Pinjam sebenarnya adalah untuk menolong dirinya sendiri dengan kekuatan atau usahanya sendiri.

a. Penyimpanan

Merupakan suatu upaya yang dilakukan oleh seseorang untuk menyisihkan pendapatannya untuk ditabungkan demi masa depan dan selebihnya untuk dikonsumsi demi terciptanya kehidupan yang sederhana.

\section{1) Simpanan Pokok}

Simpanan yang wajib dibayarkan oleh setiap calon anggota pada saat menjadi anggota koperasi, simpanan ini hanya dibayar pada awal pendaftaran saja dan tidak dapat diambil selama masih menjadi anggota koperasi tersebut.

2) Simpanan Wajib

Simpanan yang jumlahnya sudah ditentukan dan harus disetor oleh semua anggota koperasi. Simpanan ini dapat diambil dengan cara yang diatur dalam anggaran dasar dan rumah tangga koperasi.

3) Simpanan Sukarela

Simpanan yang sifatnya sukarela dan tidak diwajibkan bagi anggota koperasi, simpanan sukarela adalah transaksi yang dilakukan oleh anggota koperasi yang ingin menyimpan sebagian dari penghasilannya.

\section{b. Peminjaman}

Peminjaman adalah suatu upaya yang dilakukan seseorang atau anggota koperasi untuk memenuhi kebutuhannya karena faktor ketidakmampuan secara ekonomi.

\subsection{Konsep Dasar Java}

Java adalah suatu jenis teknologi pemrograman yang dikembangkan oleh sun microsystem, teknologi java dapat digunakan untuk membuat aplikasi database, web, jaringan, dan grafis [8]. Java adalah Bahasa pemrograman yang berorientasi objek $(O O P)$ dan dapat dijalankan pada berbagai platform sistem operasi. Perkembangan java tidak hanya terfokus pada satu sistem operasi, tetap dikembangkan untuk berbagai sistem operasi dan bersifat Open Source.

\section{METODOLOGI}

Metode penelitian yang digunakan oleh peneliti adalah metode grounded research yaitu suatu metode penelitian berdasarkan pada fakta dan menggunakan analisis perbandingan dengan tujuan mengadakan generasi empiris, menetapkan konsep, membuktikan teori, mengembangkan teori, mengumpulkan data dan analisa data dalam waktu yang bersamaan. Dalam riset ini data merupakan sumber teori atau teori berdasarkan fakta.

Langkah-langkah pokok yang digunakan pada metode ini yaitu menemukan masalah yang ingin diselidiki, mengumpulkan data dan informasi yang ada di lapangan, menganalisa dan menjelaskan masalah yang ditentukan serta membuat laporan hasil penelitian.

\section{HASIL DAN ANALISIS}

Pada penelitian ini ditemukan beberapa permasalahan yang ada pada koperasi PT Meiwa Indonesia diantaranya, sistem yang selama ini dipakai pada koperasi PT Meiwa Indonesia masih menggunakan Microsoft Excel sehingga dalam pelaksanaannya sering kali mengalami kesalahankesalahan dan kekeliruan dalam perhitungan dana transaksi. Pada laporan tahunan, petugas koperasi harus mengumpulkan data-data arsip yang cukup banyak, sehingga petugas koperasi akan membutuhkan waktu yang cukup lama dalam pembuatan dan penyusunan laporan tahunan belum adanya program yang dapat membantu dan mempermudah prose spengolahan data dan penyimpanan data yang cukup banyak. Berdasarkan analisis sistem yang sedang berjalan saat ini penyusun melihat adanya kekurangan, maka dari dibuat aturan yang akan memberikan beberapa saran sebagai alternatif penyelesaian masalah. Aturan tersebut meliputi calon anggota koperasi melakukan registrasi dengan menyerahkan fotokopi KTP, menyerahkan slip gaji, menyerahkan pas foto $2 \times 3$ satu lemba untuk pembuatan kartu anggota dan mengisi formulir pendafaran. Selanjutnya yaitu simpanan, pada awal pendaftaran diharuskan membayar Rp100.000,00 untuk simpanan pokok awal. Kemudian oetugas koperasi selanjutnya peugas koperasi membertahu kepada angggota koperasi tentang peraturan pada koperasi simpan pinjam di PT Meiwa Indonesia. Seelah itu laporan dibuat untuk mengetahui data anggota yang melakukan pinjaman setiap 
harinya dan diserahkan pada manager koperasi. Berikut gambar dekomposisi fungsi sistem.

\subsection{Diagram Alir Data (DAD) Sistem yang Berjalan}

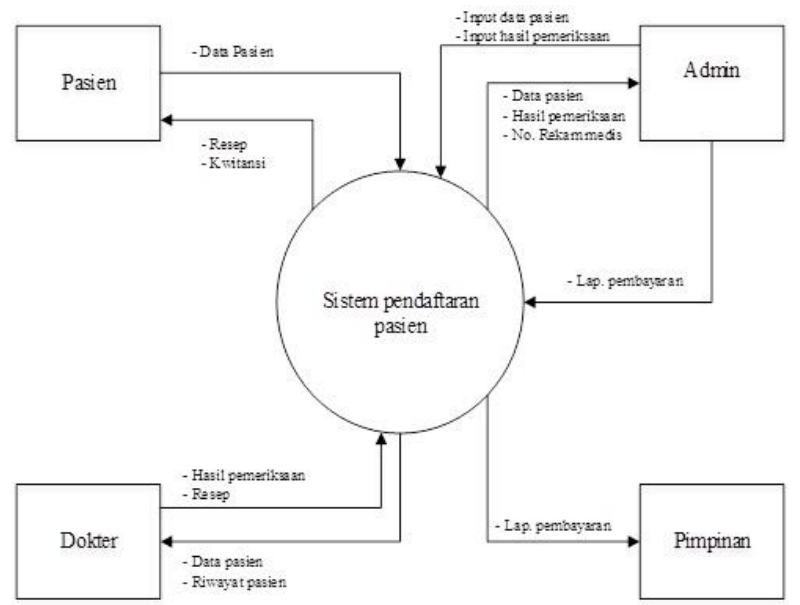

Gambar 1. Diagram Konteks Sistem Berjalan

Dari hasil penelitian penulis dapat mengambil kesimpulan bahwa :

1. Data masukan terhadap data pendaftaran dari anggota yang diterima oleh admin sistemnya belum menggunakan komputer sehingga ada laporan atau catatan yang ditulis tangan

2. Kesalahan-kesalahan pengelola data dikarenakan terlalu banyak dokumen yang harus dibuat yang menyebabkan prosedur sistem berjalan terlalu rumit

3. Pada laporan tahunan, petugas harus mengumpulkan data-data yang cukup banyak, sehingga petugas membutuhkan waktu yang sangat lama dalam pembuatannya.

\section{Alternatif Penyelesaian Masalah}

Untuk penyelesaian masalah diatas maka diusulkan beberapa alternatif

a. Membuat program aplikasi perancangan sistem informasi simpan pinjam menggunakan bahasa pemrograman untuk mempermudah dalam proses pengolahan data.

b. Program aplikasi ini akan dibuat dengan menggunakan bahasa pemrograman java dan menggunakan database MySql.

c. Data-data dari proses dan transaksi simpan pinjam ini akan disimpan dalam database.

d. Dengan penyimpanan data pada database ini diharapkan mampu mempermudah dalam proses pencarian data.

e. Pembuatan laporan tahunan juga akan dirasa cukup mudah karena petugas koperasi tinggal mencari data yang dibutuhkan dalam file-file yang ada didalam database.

f. Proses perhitungan data-data transaksi yang cukup banyak akan lebih mudah dikerjakan dengan program aplikasi ini.

g. Program aplikasi ini dibuat semudah mungkin dalam proses pengoperasiannya, sehingga pengurus koperasi tidak begitu kesulitan untuk memahami dan mempelajari proses pengoperasiannya.

\subsection{Diagram Alir Data (DAD) yang Diusulkan}

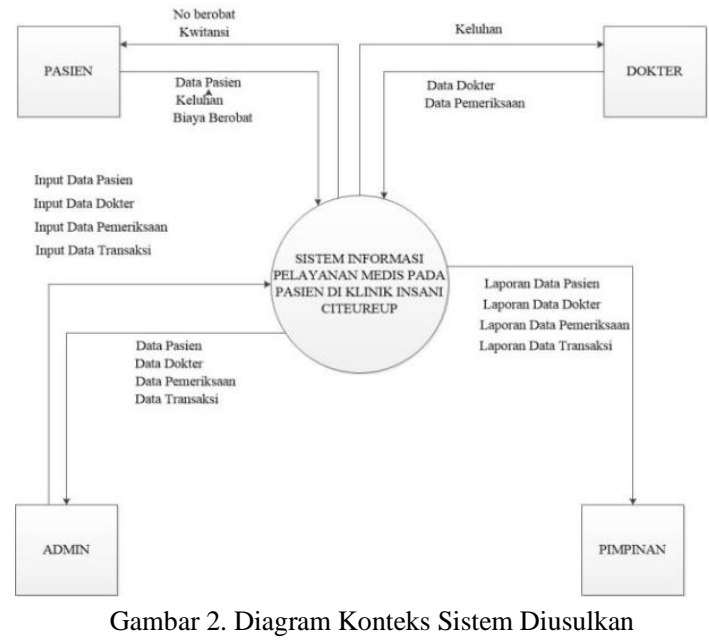

\subsection{Entity Relationship Diagram (ERD)}

Entity Relationship Diagram adalah suatu cara memodelkan suatu data di tingkat konseptual dalam perancangan basis data. Model entity relationship merupakan alat modeling data yang populer dan banyak digunakan oleh para perancang database. Data model merupakan representasi abstrak dari data tentang entitas, kejadian, aktivitas dan asosiasinya dalam suatu organisasi. ERD juga merupakan suatu model untuk menjelaskan hubungan antar data dalam basis data berdasarkan objekobjek dasar data yang mempunyai hubungan antar relasi.

Entity Relationship Diagram (ERD) merupakan sebuah teknik untuk menggambarkan struktur logis dari sebuah basis data dalam sebuah cara piktoral.

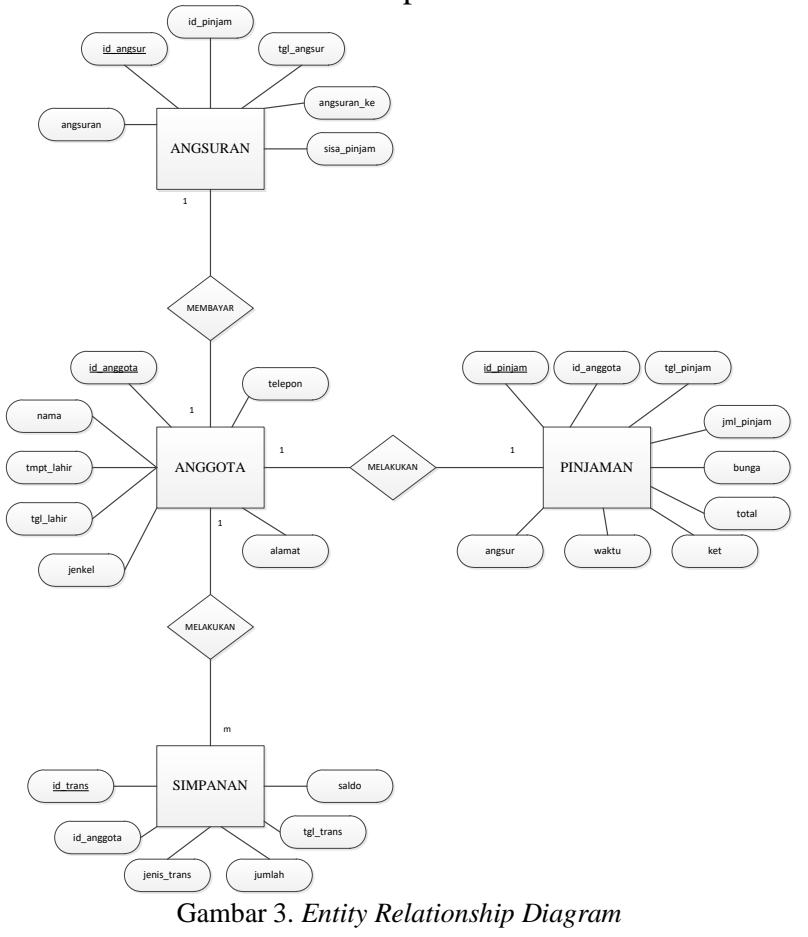

\subsection{Desain Antarmuka Aplikasi}

Berikut adalah perancangan desain antarmuka aplikasi yang akan dibuat, segala desain adalah bentuk landscape dikarenakan ini adalah desain antar muka aplikasi komputer, yang pastinya sistem ini akan memenuhi 
kebutuhan dan syarat-syarat yang perlu untuk memastikan informasi yang penting dapat disampaikan kepada pengguna aplikasi.

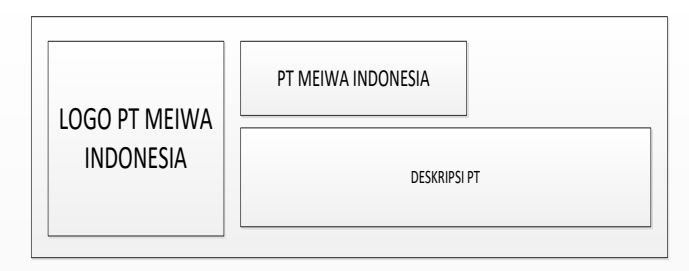

\begin{tabular}{|c|c|c|}
\hline \multicolumn{3}{|c|}{ MENU UTAMA } \\
\hline KLIK PADA MENU YANG TERSEDIA & & \\
\hline TRANSAKSI & PINJAMAN & ANGSURAN \\
\hline DATA ANGGOTA & LAPORAN & EXIT \\
\hline
\end{tabular}

Gambar 4. Desain Antarmuka Aplikasi

\subsection{Perancangan Sistem}

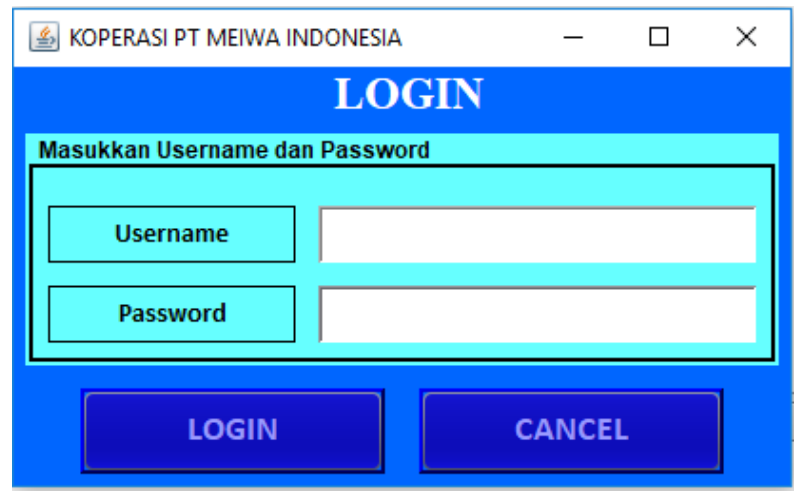

Gambar 5. Tampilan Awal

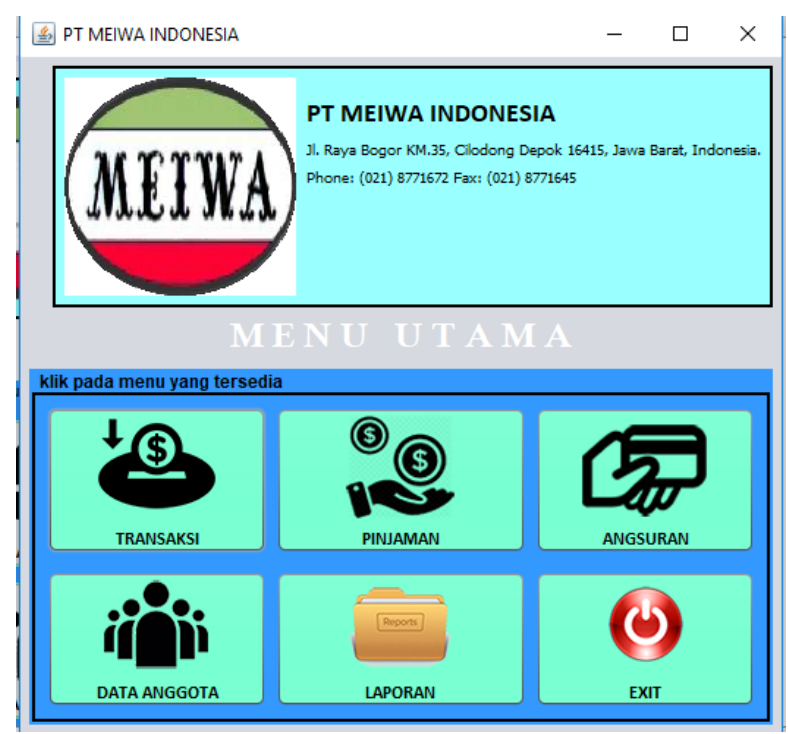

Gambar 6. Tampilan Halaman Utama
Halaman pertama yang akan dilihat pengguna aplikasi pada saat instalasi pertama, pengguna aplikasi dapat melakukan otentikasi dengan memasukkan username dan passaword yang diisi oleh admin koperasi.

Gambar 6 merupakan halaman utama aplikasi, pada halaman ini pegguna aplikasi dapat langsung melihat informasi yang dibutuhkan pada saat mendaftar.

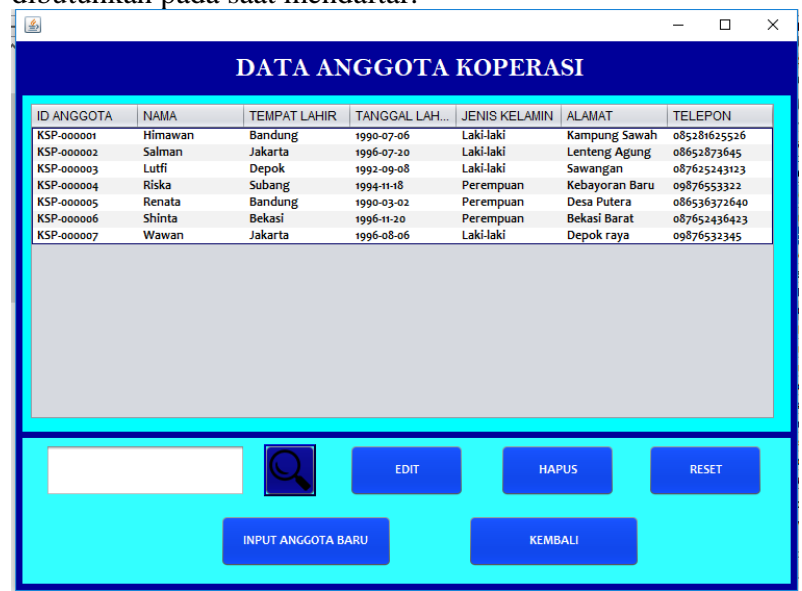

Gambar 7. Tampilan Form Data Anggota

Pada Gambar 7 admin akan menginput serta menyimpan data anggota yang sebelumnya telah di dapat dari calon anggota koperasi yang ingin mendaftar sebagai anggota.

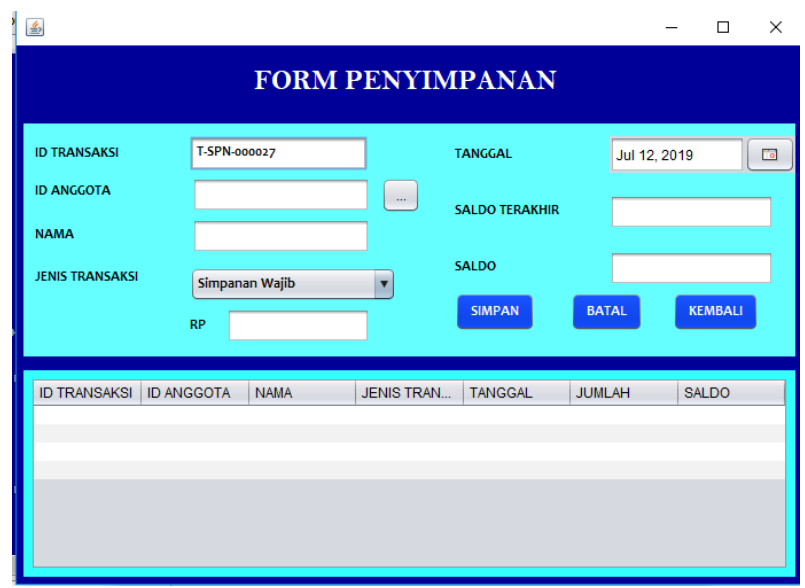

Gambar 8. Tampilan Form Transaksi Simpanan

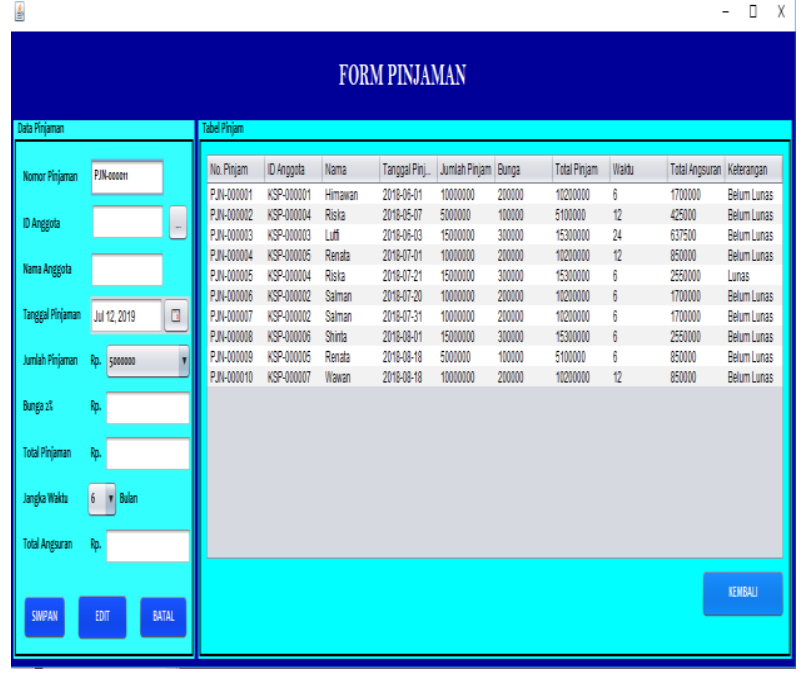

Gambar 9. Tampilan Form Pinjaman 
Pada gambar 8 Form Transaksi Simpanan pada menu ini admin akan melakukan transaksi simpanan yang telah diajukan oleh anggota sebelumnya, dan simpanan tersebut akan disimpan di data simpanan.

Pada gambar 9 Form Pinjaman pada menu ini admin akan menginput dan menyimpan data pinjaman yang diinginkan oleh anggota koperasi yang sebelumnya harus di verifikasi oleh manager koperasi.

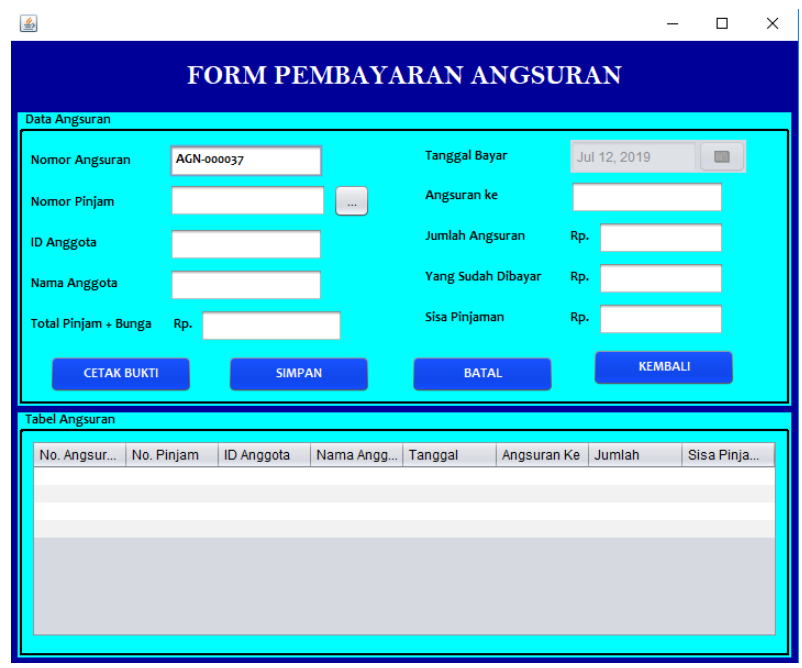

Gambar 10. Tampilan Form Angsuran

Tampilan Form Angsuran pada menu ini akan dicatat berapa kali angsuran yang akan dibayar dan yang sudah dibayar oleh anggota koperasi yang melakukan pinjaman pada koperasi.

\subsection{Tampilan Laporan Sistem}

\begin{tabular}{|c|c|c|c|c|c|c|}
\hline MEIWA & & \multicolumn{4}{|c|}{$\begin{array}{l}\text { KOPERASI SIMPAN PINJAM } \\
\text { PT MEIWA INDONESIA } \\
\text { Iogor KM.35, Cilodong Depok 16415, Jawa Barat, Indonesia } \\
\text { Phone: (021) } 8771672 \text { Fax: (021) } 8771645\end{array}$} & 3 \\
\hline \multicolumn{7}{|c|}{ LAPORAN DATA ANGGOTA } \\
\hline D ANGGOTA & 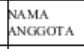 & $\begin{array}{l}\text { FEMPAT } \\
\text { EAHR }\end{array}$ & $\begin{array}{l}\text { TANGGALL } \\
\text { AMAR }\end{array}$ & $\begin{array}{l}\text { EinNS } \\
\text { KELLAII }\end{array}$ & МL.АMAт & HELPFoN \\
\hline kSP-000001 & Himawan & Bandung & | $/ 7 / 1990$ & -akk-laki & kampung Sawah & n\$85281625526 \\
\hline kSP- -000002 & Salman & Jakata & 201//1996 & -akk-laki & -enleng Agung & 88652873645 \\
\hline KSP-000003 & Lutfi & pepok & $\beta / / 1992$ & akk-laki & Sawangan & p87625243123 \\
\hline kSP-000004 & Riska & Subang & $18 / 11 / 1994$ & Perempuan & Kebayoran Baru & 99876553322 \\
\hline kSP-000005 & Renata & Bandung & $2 / 3 / 1990$ & Perempuan & pessa Putera & \$86536372640 \\
\hline kSP-000006 & Shinta & Bekasi & $2 a / 11 / 1996$ & Perempuan & Bekasi Barat & p87652436423 \\
\hline KSP-000007 & Wawan & lakata & $18 / 1996$ & akk-laki & pepok raya & 99876532345 \\
\hline & & & & & $\begin{array}{l}\text { Jakata, } 12 \text { Ju } \\
\text { PT Meiwa Ind }\end{array}$ & Uif 2019 \\
\hline
\end{tabular}

Gambar 11. Tampilan Laporan Data Anggota

Tampilan Laporan Data Anggota pada laporan ini terdapat data-data anggota yang akan diserahkan dan ditandatangani oleh Kepala Koperasi PT Meiwa Indonesia.

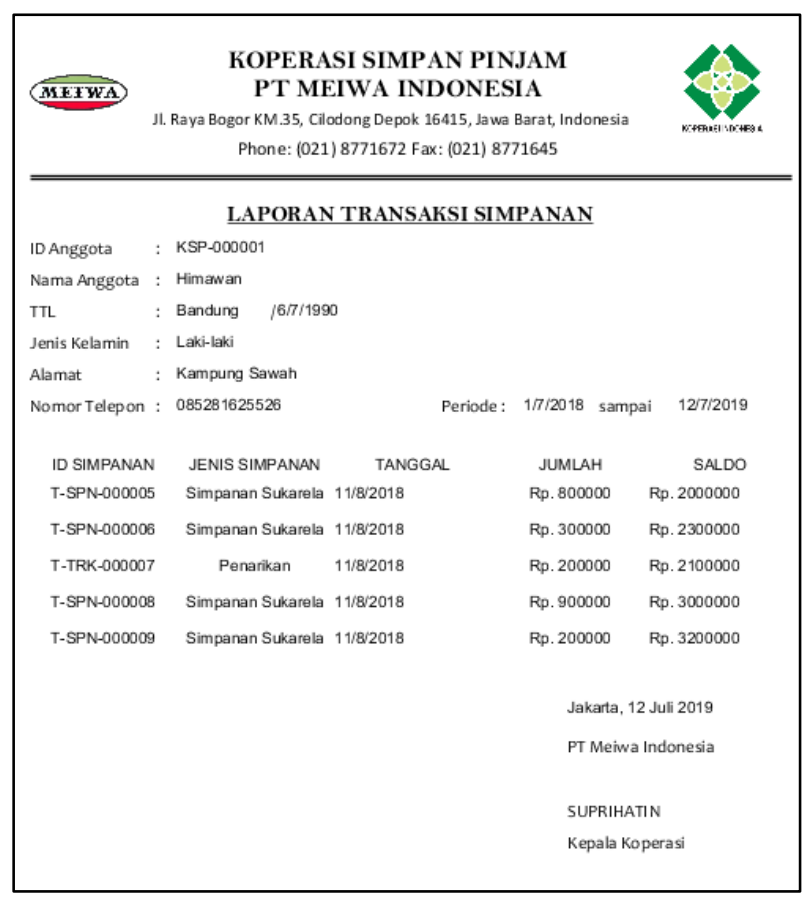

Gambar 12. Tampilan Laporan Data Simpanan

Tampilan Laporan Data Simpanan pada Laporan ini terdapat data simpanan anggota yang akan diserahkan dan ditandatangani oleh Kepala Koperasi PT Meiwa Indonesia.

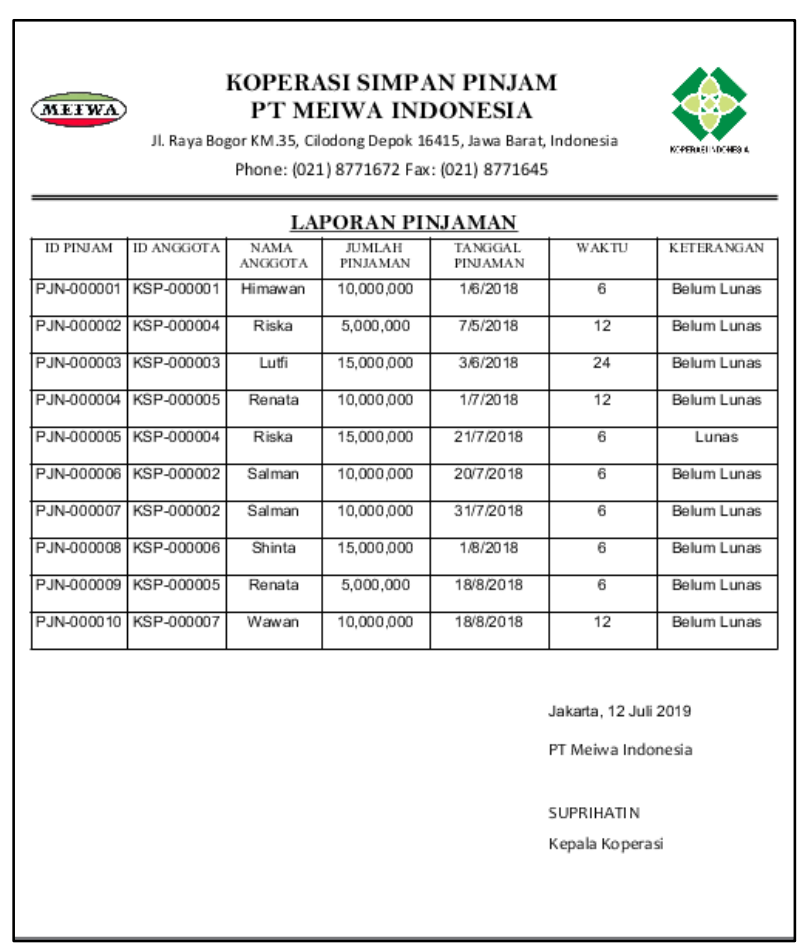

Gambar 13. Tampilan Laporan Data Pinjaman

Tampilan Laporan Data Pinjaman pada Laporan ini terdapat Data pinjaman anggota koperasi yang akan diserahkan dan ditandatangani oleh Kepala Koperasi. 


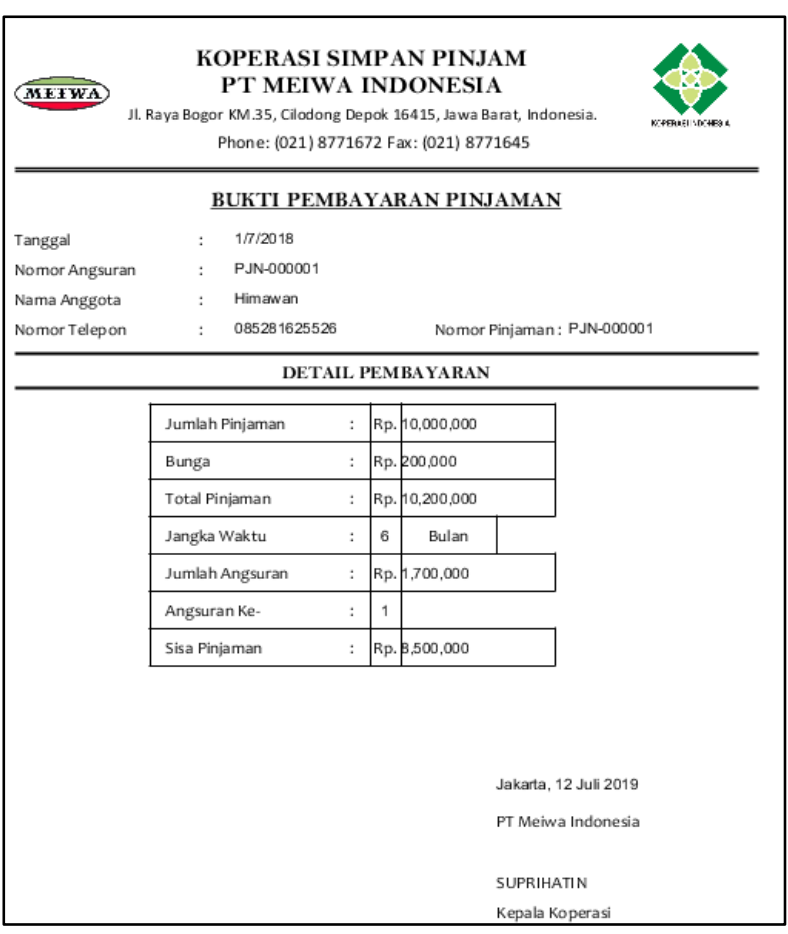

Gambar 14. Tampilan Laporan Bukti Angsuran

Tampilan Laporan Bukti Angsuran pada Laporan ini terdapat detail pembayaran sebagai bukti bahwa angsuran telah dibayar, laporan ini akan diberikan kepada anggota koperasi setelah ditandatangani oleh Kepala Koperasi.

\section{KESIMPULAN}

Berdasarkan hasil pembahasan yang telah diuraikan pada bab-bab sebelumnya dan menyesuaikan dari rumusan masalah yang ada, maka kesimpulan yang diperoleh penulis adalah :

1. Merancang sistem informasi koperasi simpan pinjam pada PT Meiwa Indonesia berbasis Java untuk membantu dalam melakukan pengolahan data pinjaman serta mempermudah petugas dalam proses pengumpulan data untuk pembuatan laporan.

2. Sistem yang dipakai pada koperasi PT Meiwa Indonesia memungkinkan pengurus angotanya dapat menjalankan proses simpan pinjam secara tepat dan efisien.

3. Dengan adanya sistem berbasis komputer, proses manajemen data dan informasi menjadi lebih efektif, menghasilkan output yang lebih cepat sehingga masalah-masalah yang terjadi pada koperasi PT Meiwa Indonesia dapat terselesaikan.

\section{DAFTAR PUSTAKA}

[1] D. Puspitasari, "RANCANG BANGUN SISTEM INFORMASI KOPERASI SIMPAN PINJAM KARYAWAN BERBASIS WEB," None, 2015.

[2] Yakub, "Pengantar Sistem Informasi," Igarss 2014, 2014, doi: 10.1007/s13398-014-0173-7.2.

[3] A. Mulyanto, "Sistem Informasi Konsep dan Aplikasi," Yogyakarta: Pustaka Pelajar, 2009, doi: 10.1007/s13398014-0173-7.2.

[4] A. Sidik, Sutarman, and E. R. Sihotang, "Perancangan Sistem Informasi Pengolahan dan Dokumentasi Ijazah Pada
SDS Penabur Ilmu Tangerang,”J. SISFOTEK Glob., 2019.

[5] T. Wahyono, Sistem Informasi (Konsep Dasar, Analisis Desain dan Implementasi). 2004.

[6] M. [1] M. Tata Sutabri, S.Kom., "Komponen Sistem Informasi," in Analisa Sistem Informasi, 2012, p. 39.Tata Sutabri, S.Kom., "Komponen Sistem Informasi," in Analisa Sistem Informasi, 2012.

[7] P. Pratiwi and A. Herliana, "ANALISIS DAN DESAIN SISTEM INFORMASI SIMPAN PINJAM PADA KOPERASI SEJAHTERA BERSAMA BANDUNG," $J$. Inform., 2016, doi: 10.31311/ji.v2i1.71.

[8] Audri, "Modul 7: Java Exception," PBO, 2016.

\section{BIODATA PENULIS}

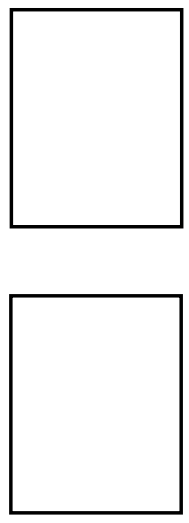

Nurrihman

Universitas Indraprasta PGRI

Rudi Apriyadi Raharjo

Universitas Indraprasta PGRI

Anggun Citra Dini Dwi Puspitasari

Universitas Indraprasta PGRI 